TITLE:

\title{
Wage Determination and Distribution in Japan(Abstract_要
} 旨)

AUTHOR(S):

Tachibanaki, Toshiaki

CITATION:

Tachibanaki, Toshiaki. Wage Determination and Distribution in Japan. 京都大学, 1999, 博士(経済学)

ISSUE DATE:

1999-05-24

URL:

http://hdl.handle.net/2433/181281

RIGHT: 


\begin{tabular}{|c|c|}
\hline 氏 & 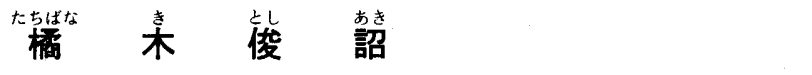 \\
\hline 学位(専攻分野) & 博 士 (経済学) \\
\hline 学位記番号 & 論 経 博 第 236 号 \\
\hline 学位授与の日付 & 平成 11 年 5 月 24 日 \\
\hline 学位授与の要件 & 学位規則第 4 条第 2 項該当 \\
\hline 位論文題目 & Wage Determination and Distribution in Japan \\
\hline
\end{tabular}

（日本における賃金決定と分配）

論文調査委員坠授 菊池光造教授森棟公夫教授久本憲夫

\section{論 文 内 容 の 要 旨}

本論文は日本の賃金決定と分配について，戦後の動きがどうであったかを分析したあのである。貨金所得は所得を構成す る中で最む大きなシェアーを占めており，それを経済学的に分析することは所得分配を分析することにつながるので価値が ある。もう 1 つの意義は，賃金は労㗢市場の動向を決める上で最も重要な变数であり，雇用や失業の決定に果たす役割を知 ることにある。

本論文は賃金決定と分配に関する経済理論の諸仮説が，デー夕によってどれだけ支持されるかを計量経済学的に検証しょ うとしたあのである。経済理論としては既存のものと著者自身のあのが検証されている。実証に際しては, 集計された公表 データと個票の両方が用いられている。

第 1 章では, この本のモティベイションと日本の労㗢市場の簡単なサーベィ, そして第 2 章以下の要約が示されている。 前半では日本の労働市場か欧米のそれとどこが異なるかが議論され，この本が欧米の労働市場の分析と異なる点がごこにあ るかが示される。特に「終身雇用」「年功序列」「企業列組合」の 3 つの特色によって, 日本の労働市場を認識することの意 義と限界が強調される。後半では日本の労働市場のむっているメリットとデメリットが簡単に議論される。

第 2 章では，賃金決定と分配に関する経済理論のいくつかが紹介され，かつ議論される。特に日本の賃金を理解する上で 重要な考え方，例えば人的資本理論，スクリーニング仮説，努力仮説，効率貨金仮説，支払い可能仮説，等々が議論される。 後半では日本の賃金決定に関する実証分析のいくつかが紹介され，それらが批判的に検討される。

第 3 章は，戦後の貨金決定に関して，どの变数を中心に影響力の変化があったかを，時系列データを用いて検証するすの である。貸金決定に影響を与える变数として，性，年齢，勤続年数，教育，職業，企業規模の 6 種が考虑され，分散・共分 散分析法を用いて，どの変数の影響力がどう変化したかを調べる。

次のようなことが本章でわかった。わが国の賃金格差を説明する上で，最す重要な变数は性，すなわち男女間貨金格差で ある。次に重要な变数は，勤続年数と年齢である。ここで人的資本理論と生活保障仮説が解釉される。さらに $10 \%$ から $15 \%$ のウェイトで企業規模格差が続く。教育之職業の効果は, 男子のホワイト・カラー職を除いて，小さいことがわかった。こ れらの性質は他の要因を考慮していない, 表面上の格差であって, 後章で詳しく検討するように, その性質は修正を受ける ことになる。

第 4 章は，賃金分配を企業規模間格差に時化して分析する。この章の特色は，企業規模間格差を純粋に注出したことにあ る。わが国における大企業と中小企業の間の賃金格差は「二重構造」として知られているが，ここでは純粋な格差はどれほ どであるかを統計的に推定したあのである。例えば，大企業には学歴の高い人が多くいるが，それらの影響力を除去する必 要がある。他の要因についても同様のことを行う必要がある。

結果として得られた事実は，わが国の企業規模間格差は他の要因を除去しても，相当大きな量である。この章は集計され た公表データではなく，個票を使っているので，他の要因の除去が，ここでなされたように計量経済学的に可能である。さ らに, 集計されたデータでは追求できない, 零細企業と巨大企業の影響力も考慮したことが貢献している。この事実をふま 
えて,レント・シェアリング仮説と支払い可能仮説が提唱される。

第 5 章は，産業間賃金格差の分析を行う。産業間格差を説明する最も大きな要因は，規模間格差の反映であると計量的に 主張される。すなわち, 平均賃金の高い産業には大企業が多く集中し, 平均顀金の低い産業には中小企業が集中しているこ とになる。本章はこのことから，欧米で支持の高い効率賃金仮説を支持しない。むしろ日本の賃金格差を説明する要因とし て，企業規模間格差は考えられているより大きく，しかも本質的であると主張される。この章の最後では，労働条件の差を 補償するメカニズムが, 日本の賃金制度にあるかどうかがテストされるが，この補償仮説は否定される。

第 6 章は, 第 7 章の主要テーマである, わが国の賃金制度と昇進制度を解明する際の理論が解説される。これらは経済学 からの要因のみならず, 社会学や組織論の力む借りるので, 経済学の理論と共にそれらが議論される。

第 7 章は，わが国の企業組織において，教育や職業，地位がごのような影響力をむって賃金を決定しているかを数量的に 分析する。さらに, 労働者が企業内で昇進するメカニズムは何であるかを調査する。ここで昇進とは, 平社員 $\rightarrow$ 係長 $\rightarrow$ 課長 $\rightarrow$ 部長への昇進を意味する。

わが国の昇進を決定する要因は，教育と勤続年数であることがわかる。ここで教育とは，中高卒業者と短大・大学卒業者 の差に注目すると，いわゆる教育がスクリーニング仮説として作用していると主張される。しかし，昇進に有利な短大・大 学卒業者であってあ, 勤続年数む結構重要であることが示される。最後に, 賃金格差における昇進, なわち昇進しない人と 昇進する人の差には, 大きな影響力があると主張される。

第 8 章は，賃金決定理論を著者独自の展開で行って，わが国を念頭においた理論仮説が提出される。それは日本の労働者 と企業行動を基に展開されており，数学的な解析に先ず取り組む。そして賃金が勤続年数, 企業規模, 教育の 3 つの変数の みによって説明されるモデルを提出する。そのモデルをデー夕に応用して実証するが，企業を移動しない人に関しては実証 に成功しているが，企業を移る人に関しては成功していない。内部労働市場論の現実妥当性を物語っているが, 外部労働市 場を考慮した賃金决定論はこれからのことといわざるをえない。

第 9 章は，男女間の賃金格差と産業間賃金格差（特に競争産業と非競争産業）に注目して，それぞれの格差を真に説明す る要因は何であるかを調べる。前者に関しては，男女間の賃金格差は男女の資質の差というよりも，女性への差別的処遇に よるところが大きいことがわかる。後者に関しては, 産業間格差の相当部分が企業規模間の差によって説明されるとされる。 それは非競争産業に大企業が多く，競争産業に中小企業が多いことの反映である。

第 10 章は，賃金分配における個人のもっている意味の解明である。個人の賃金分配がある時期に一定の確率の分布関数 (ここでは対数ロジスティック関数）に依存する場合に, 生産賃金がどのような分布に達するかを数学的に解析する。特に所 得分布の上位にいる人（能力の高い人や生産性の高い人）と下位にいる人（能力の低い人や生産性の低い人）の差が，他の 要因（例えば教育や企業規模）と比較して，どちらの要因によってより大きく説明されるのかを統計的に検証する。実証の 結果, 前者の方が後者よりあ影響力の大きいことがわかった。これは賃金分配を平均の話ではなく，個人の能力，生産性の レベルまで入って議論する必要性を説いていることになる。

第 11 章は，わが国の労働市場は伸縮性が高いと外国から評価されているが，それを詳しく検討する。確かに労働時間や ボーナス支給額の伸縮性の高いことが, 労働市場の良好なパフォーマンスに役立っているが, 逆に硬直性の高い分野す多く あることが指摘される。

第 12 章では，以上の分析でわかったことが，簓条書きで結論とし述べられている。

\section{論文電査の結果 の 要旨}

本論文は,わが国の賃金決定と分配を総合的に分析したあのである。特に戦後のわが国の賃金間題を中心にした労働市場 のパフォーマンスは，良好とみなされているが，それを理論と実証の両面から再検討しようとしたすのである。顀金決定論 の類書はあるが，他とは趣を異にする本論文の特徴点を中心に，評価を試みたい。

第 1 に，客観的に保証された本論文の質の高さが注目される。本論文の各章の内容は，元をたどれば外国のレフェリー付 きの学術誌に掲載されたものが原型になっており, 既にその段階で一定の質の高さが確保されているといえる。そのうえで, 本論文は Oxford University Press から出版されており, OUP の選定するレビュアーのスクリーニングを受け,レビュアー の指示による書き直しが再度行われている。いわば 2 段階の質のコントロールが行われているのであり，このことが本論文 
の質の高さを確証していると言える。国際的学術誌に載った書評が本論文を極めて高く評価したことも不思議ではない。一 例を挙げれば, Journal of Japanese Studies に掲載された Robert Boyerによる書評は, 本書に極めて高い評価を与えてい る。こうした事実からあ本論文の質の高さが認められるであろう。

第 2 に, 本論文は, わが国労働市場の制度的特徴を十分考慮した上で, 理論モデルの作成を行っている点と, 実証分析に あたって計量経済学の諸技法を用いて，厳密な統計的検証を行っている点に特色がある。豊富なデー夕を用いた分析の過程 では，たとえば教育と職業選択の検証に際して離散デー夕推定法を，賃金モデルの推定では非線型二段階最小二乗法を適用 するなど，最新の計量的技法を駆使している。一方，理論の面では，国際的に開発されてきた既存の諸理論を視野において， 日本の貨金決定に対するそれらの妥当性を問いなおし，新たな理論構築を試みている。我が国の経済学については，ときに 理論と実証の乘離が，その弱点として語られることがあるが，本論文は実証分析の側にやや大きく比重を置いているとはい え，意識的に理論と実証の融合を目指したあのであり，その貢献は極めて大きいと言えよう。

第 3 に，わが国の賃金決定，賃金格差，そして労働市場のパフォーマンスを，経済合理性に基づく部分と，わが国独自の 制度的特色や，個人と企業の指向や行動様式に依存する部分の 2 つに峻別し，どちらの要因がより強く作用しているかを推 定した点が本論文の優れた特色である。たとえば第 1 に，賃金決定における中高年の生活費高を考慮した生活保障仮説と， 企業訓練の成果に注目した人的資本仮説の比較か試みられる。第 2 に，男女間の賃金格差については，差別要因と非差別経 済要因の峻別の上に立った分析が行われている。いわば経済合理性と非合理性ないし文化的要因との対比を常に考慮の対象 とし，両者の貢献比率を念頭において分析している点に著者の独創性と、ゆき届いた分析視角をみることができる。

第 4 に, 本論文のいま一つの特徵は, 第 1 章から第 12 章まで分析の流れがスムーズであり, 高度な内容を扱いながら 1 編 の書物として成功している点にある。すなわち，第 1 章から順に読むことにより，貸金決定の諸作用因と賃金格差を生み出 す諸要因，さらには労㗢市場メカニズムにいたるまで，網羅的に賃金と労働をめぐる問題群を扱いながら，それらが系統的 にしかも容易に理解できるように, 周到な配慮で章別構成がなされているのである。しかも, 第 12 章には本書の主張が簡潔 にまとめられており，本論文の全体像を改めてクリアに確認することができるものとなっている。

以上，本論文は優れた研究成果だといえるが，本研究にあ問題点がないわけではない。第 1 に，この分野はわが国におい てあ経済分析に長い歴史之蓄積があるといえるが，それらの研究の消化が十全になされているとは言い難い。例えば，「二重 構造論」や「生活保障仮説」はわが国で長らく論じられ研究されてきたテーマでああり，それらの研究成果を十分に腑分け して, それらの論点と対比しつつ著者の分析結果を提示したならば，日本の読者に対しては，より説得力を持ったのではな かろうか。逆にいえば, この研究は, 英語で出版されたことに表れているょうに, 当初から欧米の研究成果と切り結ぶこと に重点を置いたものであり，そのことが論旨の展開に一定の制約を課したのだといえよう。

第 2 に，賃金決定における労働組合の役割，あるいは労使交渉の実態，さらには職場や工場レベルで何が起こっているの か，といった点についての関心が明示的には表明されていない。ある意味ではこの研究の方法からして当然のことではある が, 理論モデルと統計データの解析によって全てを描こうとする傾きが見られる。しかし, こうした分析手法による研究に あ, 実態から得られることの意味や, 実態研究の成果から学んだ点を生かし, 盛り込むことが不可能ではないはずだ。

第 3 に, 著者独自の理論提案やデー夕を用いて実証する時に, 前提となる仮定や推定のための方法に関して, もう少し慎 重な検討ないし背後にある事実への考察が望まれるという点である。本論文の根幹の 1 つをなす企業規模間の貸金格差に例 を取れば，さまざまな要因が考慮されているとはいえ，それぞれの要因間の相互依存関係について，むっと考察が必要だっ たのではなかろうか。具体的にいえば，大企業に優秀な労働者が集まることが貨金高を生む1つの原因とされているが，現 実にはその逆の因果関係むありはしないだろうか。いわば諸変数間の内生性の問題をクリアーしてから，理論モデルと実証 を行うべきであったといえよう。このような問題は本論文の他の部分にも散見されるところである。

以上，いくつかの点で本論文に望みたい点はあるが, これらはこの論文の質の高さと貢献の大きさをいささかむ傷つける あのではない。この論文が国際的な学界に貢献したところは極めて大きく，その価値は高い。よって本論文は，博士（経済 学) の学位論文として価值あるものと認める。なお, 平成 11 年 3 月 29 日, 論文内容とそれに関連した試問を行った結果, 合格と認めた。 